\title{
THORACO OMPHALO PAGUS TWIN PRESENTED AS A CASE OF RUPTURE UTERUS
}

Kiran Trivedi', D. Darukhshan Anjum²

\section{HOW TO CITE THIS ARTICLE:}

Kiran Trivedi, D. Darukhshan Anjum. "Thoraco Omphalopagus Twin presented as a case of Rupture Uterus". Journal of Evolution of Medical and Dental Sciences 2014; Vol. 3, Issue 30, July 28; Page: 8450-8452,

DOI: $10.14260 /$ jemds/2014/3068

ABSTRACT: Conjoined twins are a rare subset of monozygous twins in which incomplete division of embryonic disc occurs on $13^{\text {th }}$ - $15^{\text {th }}$ day following conception resulting in varying degree of fusion between two fetuses. ${ }^{1}$ Conjoined twins are a rare entity with an estimated incidence ranging from 1:30000 to $1: 2,00,000$ live births, ${ }^{2,3}$ and an 1 in 650 to 900 twin deliveries. ${ }^{4}$ It is also known as Siamese twins. Due to high post natal morbidity and mortality, an early pre-natal diagnosis is a must. All the monozygous twins should be carefully screened for conjoinment, type and degree of anomalies because it affects the surgical procedure done for separation. Proper management will favour better obstetric outcome.

KEYWORDS: Conjoined twin, Embryonic disc, Thoraco-omphalopagus twin.

CASE REPORT: This report presents a case of thoraco omphalopagus conjoined twin, which was referred from a village area, with features of obstructed labor in obstetrics and gynecology department in our hospital. She was 27 year old gravid 2 para 1 with one living issue, an unbooked and handled case, referred from PHC, Lohardagga. She was received in labor room in a poor condition with one dead baby hanging outside the vaginal introitus with extensive injuries to the chest wall of the hanging fetus.

Patient was immediately prepared for laparotomy along with blood in hand and was shifted to O.T. Emergency laparotomy was done, there was rupture of posterior wall of uterus. Repair was not possible thus decision of subtotal hysterectomy was taken. Both the fetuses were separated by cutting the thorax and then one fetus was delivered abdominally and the other which was hanging outside was taken from below. On examination they had 2 head, 2 pair of upper and lower limbs but shared the thorax and abdomen with single heart. Post-operative period was uneventful.

DISCUSSION: Four days after fertilization the trophoblast chorion differentiates, if the split occurs before this time monozygotic twin will implant as separate blastocyst with their own amnion and chorion. Eight days later amnion differentiates; if split occurs between $4^{\text {th }}-8^{\text {th }}$ day then twins will be monochorionic diamniotic. If split occurs between $8^{\text {th }}-13^{\text {th }}$ day monochorionic monoamniotic twins results which is a rare occurrence and accounts for 1-2\% of monozygotic twins. The embryonic disc starts to differentiate on the $13^{\text {th }}$ day then in addition to sharing amnion and chorion, they also share body parts.

Classification of conjoined twins is based on the site of union. The suffix pagus means fastened. Thorax (thoracopagus 30-40\%), abdomen (omphalopagus 25-30\%), pyopagus (10-20\%), pelvis (ischiopagus 20\%), face (cephalopagus), skull (craniopagus 2-16\%), back (rachipagus).5,6,7 thoracopagus is the most common type. 
The attempt to standardize and classify conjoined twins according to external forms is proposed by Leacham. Prognosis, obstetric management and treatment planning are determined by the degree of fusion and sharing of organs. Caesarean section is recommended in third trimester deliveries due to high incidence of dystocia and fetal damage. Antenatal diagnosis is possible in modern day obstetrics. Ultrasound identification of any of the following classical signs may suggest the diagnosis, both fetal head are at same place, unusual backward flexion of cervical spine, no change in position after changing maternal position or manual manipulation. ${ }^{4}$

Although conjoined twins are rare but should be considered in all monochorionic monozygotic twin pregnancies and ultrasonographic assessment should be carried out carefully. Siamese twins or double monsters are a subject of curiosity and mystery in general public. The present case, thoraco-omphalopagus is a rare form of conjoined twins. Indirectly emphasizing the importance of careful antenatal monochorionic twin pregnancies to rule out conjoined twins. Early diagnosis and precise characterization of conjoined twins are essential for optimal obstetric intervention and post natal management as well as to reduce psychological trauma to parents. Diagnosis of conjoined twin can help in better obstetric outcome and fetal salvage.

\section{REFERENCES:}

1. Sen C, Celik E, Vural A, Kepkep K. Antenatal Diagnosis And Prognosis Of Conjoined Twins A Case Report. J Perinat Med 2003: 31: 427-430. Http://Dx Doi. Org/10.1515/Jpm2003.066.Pmid:14601266

2. Spitz L. Conjoined Twins, Prenat Diagnosis 2005: 25: 814-9. Http://Dx.Doi.Org.10.1002/Pd.1268.Pmid:16170846.

3. Edonands L D, Layde P M. Conjoined Twins in The United States, 1970-1977.Tetralogy 1982, 25:301-8. Http://Dx.Doi.Org/10.1002/Tera.1420250306.Pmid:7112433.

4. Quioz V H, Sepulved W H, Mareado M, Bermudez R, Varela J. Prenatal Ultrasound Diagnosis Of Thoracopagus Conjoined Twins. J Perinat Med 1989:17:297-303. Http://Dx.Doi.Orvg/10.1515/Jpme.1989.17.4.297.Pmid:2696776.

5. Tongsong T, Chanprapaph, Ponsatha S. First Trimester Diagnosis Of Conjoined Twins, A Report Of Three Cases. Ultrasound Obstetric Gynaecol 1999; 14:4347. Http://Dx Doi.Org/10:1046/J 1469-0705.1999.14060434.X.X.Pmid:10658285.

6. Meizner I, Ievy A, Katz M, Glezerman M. Early Ultrasonic Diagnosis Of Conjoined Twins. Harefuah 1993; 124: 741-4. Pmid: 8375763.

7. Harper RG, Kenisberg K.Siacg, Horn D, Stern D, Bongiovi V. Xiphopagus Conjoined Twins A 300 Year Review Of The Obstetric, Morphologic Neonatal And Surgical Parameters. Am J Obstetric Gynaecol 1980; 137; 617-29. Pmid 6992583. 


\section{CASE REPORT}

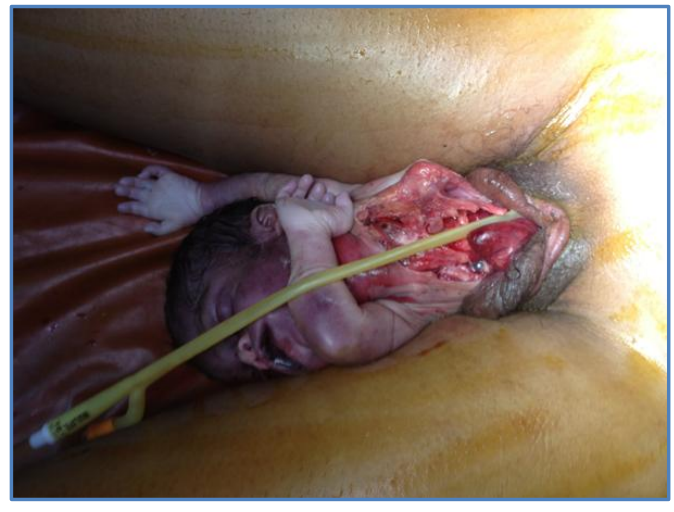

THIS PICTURE SHOWS THE DEAD FETUS EITH EXTENSIVE CHEST WALL INJURIES

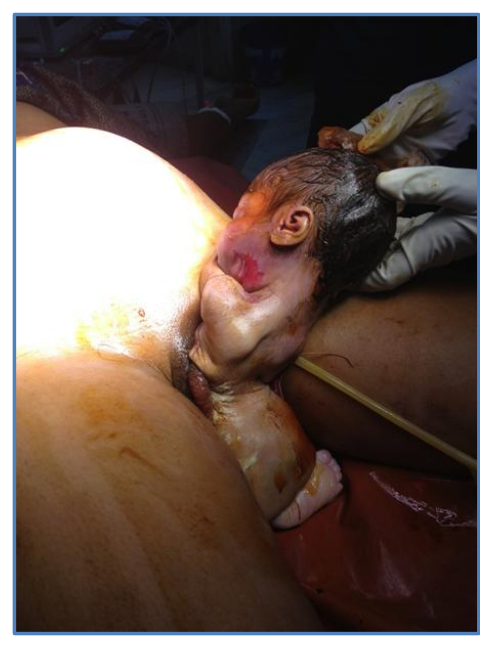

THIS PICTURES SHOWS THE DEAD FETUS HANGING OUTSIDE THE VAGINA

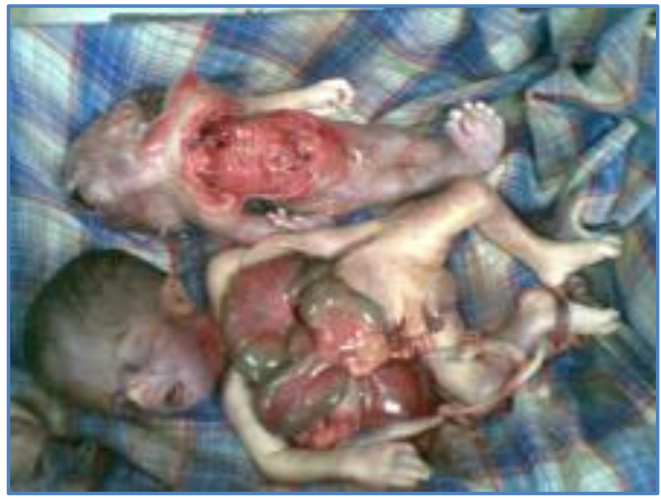

THIS PICTURE SHOWS THE FETUSES AFTER SEPARATION

\section{AUTHORS:}

1. Kiran Trivedi

2. D. Darukhshan Anjum

\section{PARTICULARS OF CONTRIBUTORS:}

1. Assistant Professor, Department of Obstetrics and Gynaecology, Rajendra Institute of Medical Sciences.

2. Junior Resident, Department of Obstetrics and Gynaecology, Rajendra Institute of Medical Sciences.

\section{NAME ADDRESS EMAIL ID OF THE} CORRESPONDING AUTHOR:

Dr. Kiran Trivedi,

Rama Nursing Home,

Main Road, Ranchi.

Email: trivedikiran2011@gmail.com

Date of Submission: 05/07/2014. Date of Peer Review: 06/07/2014.

Date of Acceptance: 16/07/2014.

Date of Publishing: 24/07/2014. 